\title{
Security and the Rule of Law in Nigeria
}

\author{
Professor Fidelis O. Okpata (Ph.D) \\ Department of Public Administration, \\ Ebonyi State University, Abakaliki \\ E-mail:onyesinachi@yahoo.com \\ Phone: 08067843346
}

\author{
Tiben Benz Nwali \\ Department of Public Administration, \\ Ebonyi State University, Abakaliki \\ E-mail:benzfreedom2@yahoo.com \\ Phone: 08037706495
}

\begin{abstract}
This study has espoused security and rule of law in Nigeria as matters of national discourse. Nigeria in recent times has been trailing through periods of insecurity of lives and property as well as none respect for the rule of law, natural justice and human dignity. To this end, the effort to build a formidable federalism in a heterogeneous society like ours is still a subject of serious debate. However, the study is objectively undertaken to evaluate the level of security and application of rule of law in Nigeria. Survey Design is the adopted methodology in which available literature were corroborated with empirical data as instruments for the analysis of issues relating to security and rule of law in Nigeria. Also, the study hinged on the Circular Causation Theory which posits that economic developments result in a circular causation process whereby the riches are awarded more favour in terms of security and respect for their civil rights while the poor are insecured and always disrespected. However, the major findings of this study are that Nigeria from the period of colonialism has been passing through turbulence years of crisis and insecurity arising from the colonial transgression that forced different ethnic groups into one nation without their consents. As a result of this, politics of bitterness and acrimony, leadership vacuum and disrespect to human dignity were the major manifestations of such activities of the Niger Delta restiveness and the Boko Haram insurgence. It was therefore recommended among other things that the leadership and political class should not politicize issues pertaining to security and that security issues should be seen by all Nigerians as collective war that should be fought and won collectively.
\end{abstract}

Key words: Security, Threat, rule of law, development

\section{Introduction}

The issue of security and rule of law in Nigeria is very broad and cuts across different fields of study. Security as an issue of national debate encompasses several disciplines such as Political Science, Public Administration, History, Sociology, Psychology, Economics, Social and Strategic Studies etc. On the other hand, rule of law, its principles and application border mostly on the fields of Political Science, Law and Public Administration.

However, the major objectives of both security and rule of law are for defense, appropriation of individual rights, protection and projection of both personal and national interests and core values within and across borders. Security is essential in both periods of war and peace times. 
However, Eke (2010) avers that in peacetime as in wartime, intelligence systems play vital role in maintaining political stability for development and progress.

Nigeria is heterogeneous state of diverse ethnic groups resulting from colonial unification that forced the ethnic groups of Northern and Southern provinces to become one entity called Nigeria in 1914. As Nwali (2011) points that since the various ethnic groups living in those provinces were not consulted regarding the unification, this colonial policy was autocratic and undemocratic and then led to fear of domination by stronger ethnic groups and conflicts of various kinds. It denied the peoples' basic needs of participation, equality and social well being as well as human dignity and rule of law. To this end, Irobi (2005) notes with dismay that an administration that endorses segregation for its people does not have the peace, unity and security of the people at heart.

Nigeria is a classic example of a country with rich human and natural resources, but without hope, arising from high level of insecurity, injustice, intimidation and negligence to the principles of rule of law and human dignity. These issues are growing worse in recent times especially with the emergence of democratic rule in Nigeria. Politics in Nigeria is no more for selfless service delivery to humanity, the end point of politics in Nigeria has become for selfaggrandizements and this accounts for the insatiable appetite for political powers among the political class for the purposes of selfish economic gains. However, since this desire cannot be achieved without political powers, desperation usually sets in to have access to state powers for self interest and upon acquisition of such state power, the fear of being oust out pre-maturely creates 'sit-tightism' syndrome among the incumbents - a circumstance that creates the desires for self-succession with do or die affairs (Nwali 2011).

The above point has created room for various violent tendencies in the country as exemplified in the then restiveness of the Niger Delta militias, the present insurgencies of the Boko Haramists and kidnapping menaces in the South East. The country has been characterized by several $\mathrm{k}$ bombing and killing of innocent souls to the utter and negligence of human dignity and rule of law. The government is doing little or nothing about the rate of violence in the country. As Greene (1974:75) painted the picture when he observed that:

violence refers to those actions by individuals or groups which endanger the physical security of people or property. The threat of violence, its actual employment and its ideological justification to political ends are among the clearest indicators of a social movements' revolutionary interest.

\section{Statement of the Problems}

Over the years, the efforts to build a formidable federalism in a heterogeneous culture with fear of political domination and perceived insecurity, social injustice and neglect to the principles of rule of law have resulted to several unrests, frustrations, deep seated hatred, insinuations and killings which indeed is tearing the country apart. Political struggles among the political class, politics of rancour and bitterness, ethnic based politics and intimidation of opposition groups the use of state apparatus to undermine others are the major sources of insecurity in Nigerian state. 
In the context of the activities which usually take place where democracy is fledging to a high esteem, security is seen as the primary responsibility of the state. Central to this fact is that the in history of man to organize into political communities has been dominated with the concern on how best to provide security of life and property which are the first order value to the state. This again highlights Hobbes social contract theory. Essentially, this concern over the security of the state has remained the defining feature of state and its relations with the individuals in their interaction and any state which fails to ensure the security of its citizens is said to have failed completely and therefore faces great challenge in governance.

More over, colonialism, violation of rights, authoritarianism, frustration by aggrieved citizens, selfish political activities, winners take all syndrome etc, are among the major contending issues that motivated this study.

In addressing these issues, the study attempted to find answers to the following questions:

- What are the major factors affecting security and application of rule of law in Nigeria?

- What are the implications of insecurity and non application of rule of law in Nigeria?

- What are the roles of government in ensuring security and human dignity in Nigeria?

\section{Objectives of the Study}

Broadly, the study is meant to evaluate the level of security and application of the rule of law in Nigeria. Other specific objectives are:

- $\quad$ To determine the major factors affecting security and the application of the rule of law in Nigeria.

- $\quad$ To evaluate the implications of insecurity and non application of rule of law in Nigeria

- $\quad$ To assess the roles of government in ensuring security and hu ,man dignity in Nigeria.

\section{Methodology}

The adopted methodology for this study is the survey design. Available literature shall be explored in corroboration with available statistical data to analyze issues relating to security and application of rule of law in Nigeria.

\section{Conceptual Clarifications}

\section{Threat:}

According to Hornby (2005) threat is the possibility of trouble, danger or disaster. He equally sees threat as something as a person or thing that is likely to cause trouble. Dammadami (1985) cited in Oboke, Eje and Igwe (2012) submitted that threat has ordinarily been defined as a feeling whether real or imaginary by one being that another being has hostile intentions against him. According to Imobighe (1980) threat can be perceived as well as manifested by actions. Threat therefore in this context of internal security of a country may be seen as a situation in which individuals or group through verbal utterances and/or resorting to physical application of 
force with the use of small arms to create dangers in a typical societal environment such that the inalienable human rights as are jettisoned.

\section{Security:}

Security in the words of Trout and Herf cited in Ifesinach and Eke (2009) is a state of mind of several individuals within which range of physical leadership rationalize their quests for security, raise and maintain military power in order to be strong and effective in the pursuit of its interests. From the above view, security of individual rests first on the actions of the individuals but the bulk of the work depends heavily on the ability of the leaders to raise and maintain military powers and other internal forces that will be able to have effects on the pursuit of both personal and national interest. However, Greene (1981) points that security is a state of relatively predictable environmental conditions which an individual or group of individuals may pursue its needs without deception of harm and without fear of disturbances or injury. It is important to state here that security is a man-made scenario positively and inversely such that each side has its attendant consequence of peace and/or troubles respectively. Observing the imperatives of security in the society, Rockely and Hill (1981) assert that the need for security is confirmed with unfailing regularity because the scope of problems resulting from lack of it is enormous. Akpuru-Aja (1997) believes the above scholars when he averred that system maintenance against anarchy or lawlessness is an index of peace and security, maintaining that system in this view could be a community, a state, a nation or world at large.

\section{Rule of Law:}

Okoli (2013) says that the idea of the rule of law is not new, but it is bound up with the liberty of the citizens, maintaining that all through the ages, philosophers have grappled with the problems of safeguarding the liberties of citizens so as to avoid tyranny or arbitrary exercise of government powers over citizens.

The historical development of the rule of law is traceable to great the philosophers as Plato, Aristotle, A.V. Dicey and others. Plato for example in the Republic believes that only philosopher kings should be allowed to govern because they are all-wise and could devote their whole life to the art of government. In this way, they could protect and advance the interest of their subjects. Later in the laws, he changed his mind and called for the rule by the laws because the philosopher king is difficult to find and even when found, he is not likely to live above his human inclinations, but the rule by the laws combines both the wisdom of the ages and the finality of the king. Hence, the rule by the law is best of the practical and possible process of government (Okoli, 2013).

However, Aristotle later proffered that the rule of law is preferred to that of any individual. The writings of these two great philosophers made the idea of rule of law to gain popular acceptance. Thus, in the middle ages, the view that the world was governed by law, whether human or divine, was already a popularly held value (Okoli, 2013). 
Moreover, this view had been popularly held as part of political philosophy by people like Brockton who was of the view that the king itself aught not to be subject to man, but to God and to the law, because the law makes him king.

The current idea of the rule of law owes much to the writings of A.V. Dicey (1885) who articulated and expounded the principles of the rule of law. According to him, the rule of law has three discernible facts which includes

Supremacy of the Law which means the absolute supremacy or predominance of regular law as opposed to the influence of arbitrary power and excludes the existence of arbitrariness of prerogative or even of wide discretionary authority on the part of the government. This means that governmental powers must be exercised in accordance with the laws of the land and nothing more.

Equality of all Men before the Law which means the equal subjection of all classes to the ordinary law of the land administered by the ordinary courts. The rule of law in this sense excludes the idea of any exemption of officials or others from the duty of obedience to the law which governs the land. By implication, every citizen irrespective of sex, race, occupation, rank, or status etc is subject to the ordinary laws of the land without discrimination.

Inherent and Inalienable Rights of Citizens which according to A.V. Dicey should include, right to life, right to dignity of human person, right to personal liberty, right to fair hearing, right to private and family life, right to freedom of thought, conscience and religion, right to freedom of expression and the press, right to peaceful assembly, right to freedom of movement, right to freedom from discrimination.

In Nigeria, cases of violation of human rights, none equality among the citizens such as the immunity clause in the constitution and rest of them are issues that needs to be addressed. Any violation or threat to the rights mentioned above amounts to insecurity and none respect to human dignity and these cases are prevalent in Nigerian societies.

\section{Theoretical Foundation}

The study is hinged on Circular Causation Theory. The circular causation theory is one of the economic theories propounded by Gunnar Myrdal. The major postulation of Myrdal in this theory is that economic development results is a circular causation process whereby the rich are awarded more favours (in terms of security and respect) and the effort of those who lag behind are threatened and neglected. Jhingan (2003:211) captured Myrdal's major position thus:

In undeveloped countries, a circular and cumulative process also known as the 'vicious circle of poverty' operates downwards and being unregulated causes of increasing inequalities.

Myrdal is of the view that our inherited theoretic approach is inadequate to solve the problem of economic inequalities, insecurity and respect to human dignity. This, according to him is because the traditional economic theory was based on the unrealistic assumption of stable equilibrium. 
He finally averred that it is wrong to apply the notion of stable equilibrium for constructing a theory to explain the change in a social system.

Going by the propositions of Myrdal in circular causation theory, there is no such tendency towards automatic self-stabilization in the social system in the normal situation. This is because the social system is not by itself moving towards any sort of balance between forces, but is constantly on the move away from such a situation. This stems from the fact that the change does not call forth contracting changes, but instead, supporting changes which move the system in the same direction as the first change, but much further. Based on such circular causation, a social process tends to become cumulative and often to gather speed at an accelerating rate.

The substance of this theory which makes it relevant to this study is that the gap between the rich and the poor masses in Nigeria is exacerbating and there is no concrete plan and comprehensive programme to launch Nigeria into relative poverty reduction, youth development and employment which will serve as a veritable tool of livelihood and economic development. More so, the issue of the rich not regarding the rights of the poor masses and the continued widening gap between the poor and rich with the wrong practical philosophy of the winner takes all, culminated to the major reasons for Boko Haram insurgence, kidnapping, armed banditry and violence in Nigeria.

\section{Imperatives of Security for National Development}

The current security challenges in Nigeria have become a serious threat to the peace, stability and development of the country. This situation is worrisome to the people within and international organizations. Scholars such as Nnadozie, Ige, Anaba, and Abudulah (2004:23) agreed with this fact when they decried that:

The security situation in the country is one of the problems threatening our democratic government. From disturbing political killing to dare devil banditry, the result is the same helplessness. There is now a bizarre situation where the high and low are gripped by fear...rather than reducing the menace, armed gangs have graduated from attacking innocent citizens at night to engaging law enforcement agents in gun duels in broad day light.

In a situation of security dilemma such as the one Nigeria fins herself now, there could be no better strategy of defence than offensive defense if meaningful development is to be attained. This has to be done by taking proactive measures of preemptive actions to the war-head-long to the creeks, villages and terrorist enclaves in the surrounding bushes and uncompleted buildings littering Nigerian states. But disappointingly, the authorities lack the moral fibre to confront the problem because of obvious case of negligence and injustice against the poor masses. Nigerian government and security agencies should for once dedicate themselves to genuine war against insecurity by fighting cultism in schools as their breeding grounds and disarming their gun runners during and after political campaigns. It is believed that Nigerian government should consider the humble view of Bran in Erickson (1990:170) who states that: 
...Taking the risks necessary thoughtfully, but forcefully to affirm justice and sacredness even for the oppressor. Non violence, therefore seeks transformation in the oppressor. It avoids humiliating or defeating one's adversary. It seeks reconciliation and healing. It stirs conscience with militant peacefulness.

Because of the inability of government to address this situation by taking the bull by the horn, the country has been branded by international bodies as terrorist nation. Terrorism, fear of the unknown and other forms of violence and victimization against individuals or groups or the state are at the centre of insecurity. Greene (1974:77) describes terror to include:

assassination, kidnapping, bombing and is intended to disorient the psychology of individual in the social mass in the same way that sabotage is designed to disrupt the production, transport and communication systems of the state.

Over the years, especially since 2007, Nigeria has been boiling with all manner of insecurity cases ranging from restiveness, kidnapping, bombing, pipeline vandalization and rest of other social vices. In table 1 Nwali (2013) presented empirical analysis of some cases of bombing and bomb blasts in Nigeria since1986. In table 2 Nkwede (2010) shows a statistics of cases of kidnapping in the south east since 2007 while in table 3, Onuoha (2007) presented different cases of oil pipeline vandalization and fire disasters in the Niger Delta region of Nigeria.

Table 1: Selected Cases of Bombing and Bomb Blasts in Nigeria Since 1986

\begin{tabular}{|c|c|c|c|c|}
\hline S/N & DATE & PLACE & SUSPECTS & VICTIMS \\
\hline 1 & $19 / 10 / 1986$ & $\begin{array}{c}\text { Dele Giwa's house: Ikeja, } \\
\text { Lagos }\end{array}$ & IBB & Dele Giwa \\
\hline 2 & $31 / 5 / 1995$ & Ilorin Stadium & unknown & Figure not known \\
\hline 3 & $18 / 1 / 1996$ & Durbar Hotel, Kaduna & $\begin{array}{c}\text { Suspect killed but } \\
\text { name not available }\end{array}$ & Figure not known \\
\hline 4 & $20 / 1 / 1996$ & Aminu Kano Int'l Airport, & unknown & Figure not known \\
\hline 5 & $11 / 1 / 1996$ & Ikeja Cantonment, Lagos & unknown & Figure not known \\
\hline 6 & $25 / 4 / 1996$ & Air Force Base, Ikeja, Lagos & unknown & Figure not known \\
\hline 7 & $14 / 11 / 1996$ & Murtala Muhamed Airport & unknown & Chief security officer \\
\hline 8 & $16 / 12 / 1996$ & Not Available & unknown & Col. Marwa's Convoy \\
\hline 9 & $18 / 12 / 1996$ & $\begin{array}{c}\text { Not Available } \\
\text { unknown }\end{array}$ & $\begin{array}{c}\text { Task force on } \\
\text { environmental sanitation }\end{array}$ \\
\hline 10 & $17 / 1 / 1997$ & Not available & unknown & Nigeria Army bus hit \\
\hline 11 & $22 / 4 / 1997$ & Evans Square & unknown & $\begin{array}{c}\text { 3 died, several people } \\
\text { injured }\end{array}$ \\
\hline 12 & $13 / 12 / 1997$ & Abuja Airport & unknown & $\begin{array}{c}\text { Lt Col. Oladipo Diya } \\
\text { escapes death }\end{array}$ \\
\hline 13 & $12 / 5 / 1997$ & Ibadan & $\begin{array}{c}\text { Federal ministry of works } \\
\text { and housing; human } \\
\text { victim not known }\end{array}$ \\
\hline 14 & $27 / 1 / 2002$ & Ikeja cantonment, Lagos & Stored bomb exploded & Over 1,000 people \\
\hline
\end{tabular}




\begin{tabular}{|c|c|c|c|c|}
\hline 15 & $15 / 5 / 2010$ & Warri, Delta State & Niger Delta Militants & Figure not available \\
\hline 16 & $1 / 10 / 2010$ & Abuja & Boko Haram & Figure not available \\
\hline 17 & $8 / 4 / 2011$ & Suleja, Niger State & Boko Haram & $\begin{array}{c}\text { INEC Office; human } \\
\text { victim not known }\end{array}$ \\
\hline 18 & $26 / 4 / 2011$ & Maiduguri, Borno State & Boko Haram & Figure not available \\
\hline 19 & $1 / 1 / 2011$ & Abuja & Boko Haram & $\begin{array}{c}\text { Army market; human } \\
\text { victim not known }\end{array}$ \\
\hline
\end{tabular}

Source: Nwali T. B. (2013)

Table 2: Cases of Kidnapping in the South-Eastern Nigeria 2007- 2010

\begin{tabular}{|c|c|c|c|c|c|}
\hline $\mathbf{S} / \mathbf{N}$ & NAME & $\begin{array}{l}\text { STATE OF } \\
\text { KIDNAP }\end{array}$ & DATE & $\begin{array}{l}\text { RANSOM } \\
\text { PRICE }\end{array}$ & LOCATION \\
\hline 1 & Mr. Niu Quijang & Anambra & $17 / 03 / 2007$ & N/A & Nnewi L.GA \\
\hline 2 & Mr.shey Feng & Anambra & $17 / 03 / 2007$ & $\mathrm{~N} / \mathrm{A}$ & $\begin{array}{ll}\text { Nenwi } & \text { L.G.A }\end{array}$ \\
\hline 3 & $\begin{array}{l}\text { Mr. Sylvester } \\
\text { Unigwe }\end{array}$ & Anambra & $17 / 03 / 2007$ & N/A & $\begin{array}{ll}\text { Nenwi } & \text { L.G.A }\end{array}$ \\
\hline 4 & ChibuikeNkwegu & Enugu & $16 / 12 / 2008$ & $\mathrm{~N} 5 \mathrm{~m}$ & University ofNigeria Nsukka \\
\hline 5 & Rev. joseph Okoye & Ebonyi & $09 / 06 / 2008$ & N/A & Abakaliki Urban \\
\hline 6 & Mr. Dave Agwada & Ebonyi & $21 / 08 / 2008$ & N/A & Abakaliki Urban \\
\hline 7 & Jonhy Okorafor & Ebonyi & $08 / 11 / 2008$ & $\mathrm{~N} 10 \mathrm{~m}$ & Awuza Quarters Abakaliki \\
\hline 8 & $\begin{array}{l}\text { Chief Chris } \\
\text { Nwaankwo }\end{array}$ & Ebonyi & $05 / 10 / / / 2009$ & N200M & $\begin{array}{c}\text { CounyiS home Ebyya Izzi } \\
\text { L.G.A }\end{array}$ \\
\hline 9 & Mr. Juliana Adum & Ebonyi & $14 / 08 / 2009$ & N80M & Meat Market Abakaliki Town \\
\hline 10 & $\begin{array}{l}\text { Master Obinna } \\
\text { Okpo }\end{array}$ & Ebonyi & $13 / 11 / 2009$ & N/A & Country Home Nkaleke Town \\
\hline 11 & $\begin{array}{c}\text { Mr.Guiceepe } \\
\text { Canova (Manager } \\
\text { Marlum Coy) }\end{array}$ & Ebonyi & $13 / 06 / 2009$ & $\mathrm{~N} 20 \mathrm{~m}$ & Abakaliki-Afikpo Road \\
\hline 12 & Nkem Owoh & Enugu & $26 / 04 / 2009$ & N/A & Nkanu L. G.A \\
\hline 13 & Mr. Pete Edochie & Anambra & $16 / 10 / 2009$ & $\mathrm{~N} / \mathrm{A}$ & Onitsha Headbridge Onitsha \\
\hline 14 & $\begin{array}{c}\text { Comrade Wahaba } \\
\text { Oba }\end{array}$ & Abia & $11 / / 10 / 2010$ & $\mathrm{~N} 250 \mathrm{M}$ & Umuafoku Obingwa .L.G.A \\
\hline 15 & $\begin{array}{c}\text { Comrade Sylvester } \\
\text { Okereke }\end{array}$ & Abia & $11 / 07 / 2010$ & $\mathrm{~N} 250 \mathrm{M}$ & Umuafoku Obingwa .L.G.A \\
\hline 16 & $\begin{array}{l}\text { Comrade Adophus } \\
\text { Okonkwo }\end{array}$ & Abia & $11 / 07 / 2010$ & $\mathrm{~N} 250 \mathrm{M}$ & Umuafoku Obingwa .L.G.A \\
\hline 17 & $\begin{array}{c}\text { Comrade Sola } \\
\text { Oyeyepo }\end{array}$ & Abia & $11 / 07 / 2010$ & $\mathrm{~N} 250 \mathrm{M}$ & Umuafoku Obingwa .L.G.A \\
\hline 18 & $\begin{array}{c}\text { Comrade Yakeen } \\
\text { Azeez } \\
\end{array}$ & Abia & $11 / 07 / 2010$ & $\mathrm{~N} 250 \mathrm{M}$ & Umuafoku Obingwa .L.G.A \\
\hline 19 & $\begin{array}{c}\text { Evangelist Jacob } \\
\text { Achilefu }\end{array}$ & Abia & $17 / 03 / 2010$ & $\mathrm{~N} 2 \mathrm{~m}$ & Aba Ikot Ekpene highway \\
\hline 20 & Prof J.U.J Asiegbu & Imo & $20 / 02 / 2010$ & N/A & Okigwe-Aba-P-H Road \\
\hline 21 & $\begin{array}{l}\text { Prof B.D Fakae } \\
\text { (VCRSUT) }\end{array}$ & Rivers & $15 / 01 / 2010$ & N/A & Niger-Delta \\
\hline 22 & Mr. Victor Udosen & Ebonyi & $4 / 07 / 2010$ & N500M & Ivo life Camp Ivo L.G.A \\
\hline
\end{tabular}




\begin{tabular}{|c|c|c|c|c|c|}
\hline 23 & $\begin{array}{c}\text { Barrister Sylvester } \\
\text { Chima Oduko }\end{array}$ & Eobnyi & $6 / 03 / 2010$ & N/A & $\begin{array}{c}\text { Okporojo Idima Edda } \\
\text { Afikp.S.L.GA }\end{array}$ \\
\hline 24 & $\begin{array}{l}\text { Mrs. Grace Ola } \\
\text { Oduko }\end{array}$ & Ebonyi & $6 / 03 / 2010$ & N/A & $\begin{array}{l}\text { Okporojo Idima Edda } \\
\text { Afikp.S.L.GA }\end{array}$ \\
\hline 25 & Dr. Sha Okorie & Imo & 26/06/2010 & N/A & $\begin{array}{l}\text { St. Joseph's Hospital Ahiazu } \\
\text { Mbaise L.G.A }\end{array}$ \\
\hline 26 & $\begin{array}{l}\text { Mrs. Grace } \\
\text { Unatoru }\end{array}$ & Rivers & $25 / 06 / 2010$ & N/A & $\begin{array}{c}\text { Shell Petroleum Dev.Coy port } \\
\text { Harcourt }\end{array}$ \\
\hline 27 & Dr. Vin Odoukwu & Imo & $3 / 9 / 2010$ & N/A & $\begin{array}{c}\text { Orlu L.G.A } \\
\end{array}$ \\
\hline 28 & 15 school Children & Abia & $27 / 9 / 10$ & $\mathrm{~N} 20 \mathrm{M}$ & $\begin{array}{c}\text { International School } \\
\text { Ekeakpara, Aba }\end{array}$ \\
\hline
\end{tabular}

Source: Nkwed, J. O (2010)

Disruption in the production, transport, communication and other sectors of the economy as a result of insecurity amount to underdevelopment. This is true as Etuk (2007:58) observes that:

The wealth of every nation is tied to the level of security they enjoy and this is the reason most responsive government strive to ensure that lives and property of citizens are protected.

Table 3: Selected Cases of Oil Pipeline Vandalisation and Fire Disasters in the Niger-Delta Region

\begin{tabular}{|c|c|c|c|c|}
\hline $\mathbf{S} / \mathbf{N}$ & Date & Location & State & Observed Consequences \\
\hline 1 & $17 / 10 / 1998$ & Jesse & Delta & $\begin{array}{c}\text { Damage to farmlands pollution, dozens of } \\
\text { people injured }\end{array}$ \\
\hline 2 & 22/04/1999 & $\begin{array}{l}\text { Bayana, Ijaw } \\
\text { Community }\end{array}$ & Delta & $\begin{array}{c}\text { Damage to farmlands, pollution (air and } \\
\text { water) }\end{array}$ \\
\hline 3 & $13 / 10 / 1999$ & Ekaphemre Ughcli & Delta & $\begin{array}{l}\text { Damage to farmlands, destruction of flora } \\
\text { and fauna; environmental pollution }\end{array}$ \\
\hline 4 & $14 / 01 / 2000$ & Gana Community & Delta & Damage to farmlands, and the environment \\
\hline 5 & $07 / 02 / 2000$ & Ogwe Community & Abia & Damage to farmlands, and the environment \\
\hline 6 & $14 / 03 / 2000$ & $\begin{array}{l}\text { Umegbede } \\
\text { Community }\end{array}$ & Abia & Damage to farmlands, and the environment \\
\hline 7 & $03 / 06 / 2000$ & Adeje & Delta & $\begin{array}{l}\text { Damage to farmlands, destruction of high } \\
\text { tension power cable of two electricity } \\
\text { plants, youths/police clash }\end{array}$ \\
\hline
\end{tabular}

\begin{tabular}{|c|c|c|c|c|}
\hline 8 & $20 / 06 / 2000$ & Okuedieba & Delta & $\begin{array}{c}\text { Damage to farmlands, and the } \\
\text { environmental pollution }\end{array}$ \\
\hline 9 & $10 / 07 / 2000$ & $\begin{array}{c}\text { Adeje/Egorede, } \\
\text { Okpe }\end{array}$ & Delta & $\begin{array}{c}\text { Dozens of people injured, damage } \\
\text { farmlands, environmental pollution }\end{array}$ \\
\hline
\end{tabular}




\begin{tabular}{|c|c|c|c|c|}
\hline 10 & $10 / 11 / 2000$ & Ovir Court & Delta & $\begin{array}{c}\text { Dozens of people injured, damage } \\
\text { farmlands, environmental pollution }\end{array}$ \\
\hline 11 & $05 / 06 / 2001$ & Umudike & Imo & $\begin{array}{c}\text { More than 17 people injured; several } \\
\text { properties bunt }\end{array}$ \\
\hline 12 & $19 / 06 / 2003$ & $\begin{array}{c}\text { Onicha Amiyi- } \\
\text { Uhu }\end{array}$ & Abia & $\begin{array}{c}\text { Dozens of people injured famage to } \\
\text { farmland }\end{array}$ \\
\hline 13 & $06 / 01 / 2004$ & $\begin{array}{c}\text { Elikpkwodu } \\
\text { Rivers }\end{array}$ & $\begin{array}{c}\text { About 20 hectares of farmland and } \\
\text { properties worth millions of Naira } \\
\text { destroyed }\end{array}$ \\
\hline 14 & $13 / 01 / 2006$ & Iyeke & Edo & $\begin{array}{c}6 \text { persons injured; damage to farmland s } \\
\text { environmental pollution }\end{array}$ \\
\hline
\end{tabular}

Source: Onuoha (2007)

\section{Factors Militating Against Operation of Rule of Law in Nigeria}

The assumptions of the rule of law are not fully realized in Nigeria because of a number of factors which include:

i. Ignorant of the Law: Most people in Nigeria are ignorant of the law and do not know their rights and obligations. Since ignorance of the law is not an excuse of the law, these people suffer untold deprivations despite the rule of law.

ii. Existence of Class Society and Class Interests: In Nigeria, because of the existence of class interest, justice is often perverted to the detriment of the common man. Many Nigerians are immuned by certain clause in the constitution, making them sacred cows over and above the law of the land.

iii. Bureaucratic Redtapism: The greatest threat to the rule of law is redtapism. Redtapism has been described as unnecessary delays in government operations and routine functions. It has become a popular maxim in the legal circles that "justice delayed is justice denied" this is a classic effect of redtapism.

iv. Cult Societies: Societies such as Ogboni, Amorc, Erkanka etc, have their way of protecting the interests of their members just like class. In a situation where members of these cults are involved, justice is usually tampered with their members.

v. High Cost of Litigation: In most developing countries, the cost of litigation or seeking redress in courts is always exorbitant. In the absence of legal aids facilities, court facilities are not available to the poor members of the society.

vi. Manipulation of the Judiciary by Government in Power: This is apparently the problem in most developing countries. For example late Dr Kwame Nkrumah of Ghana in 1964 dismissed a judge, Sir Arkuh Korsal for giving bad judgment against the government (Okoli 2013).

Implications of Insecurity and None Respect For Rule of Law on the Development of Nigerian State

There are far reaching implications of insecurity and none respect for rule of law on the development of Nigeria. This study identifies the following as the major implications: 
1. Unprepared Development Diversion: Every government has a number of strategized programmes and projects to implement at a given point in time for the good of the people. However, when there is serious security threat, the government will have to face the reality on ground. To achieve this effectively, the attention of government would be diverted unprepared. Therefore, the negative effects of this diversion would take more than necessary time depending on the degree and nature of the threat and insecurity of the threat in place.

2. Reduction/Stagnation of Development Programmes: A serious implication of insecurity on development is the reduction and/or stagnation of development programmes and projects. This happens when the state of insecurity becomes a threat on leadership, leading to leadership failures. When there is threat on security, leadership in attempt to get rid of the problem would abandon some other projects notwithstanding their importance to the people.

3. Loss of Government Revenue: Production and services are mostly affected by any threat of insecurity. This is because production in major industries is stopped until normalcy returns. This of course could lead to loss of huge amount of money accruable to government. This however affects effective implementation of projects financially. Thus, Akpuru-Aja (2007) notes that Nigeria lost 7.9 billion naira daily to Niger Delta crisis in oil revenue as a result of restiveness in the region.

4. Stagnation of Development Indicators: Most times, threats to security leads to destruction of lives and property such as buildings, government installations, cares, factories etc. It should be accepted that replacement of the affected property take much time than necessary and in most cases the vacuum created remains unclosed thereby creating scenario of development stagnation on the affected areas.

5. Social Vices Multiplying Effects: This occurs as a result of frustrations, hunger, hardship etc which the inhabitants of conflicting communities are subjected to. For example, a person or group of people may as a result of frustration indulge in such acts as prostitution, stealing armed banditry, human trafficking, kidnapping and physical violence as evident in the activities of the Boko Haram and Niger Delta militias.

\section{Major Findings of the Study}

From this study, it was found that:

i. Nigeria from the period of colonialism to date has been passing through turbulence years of crisis and insecurity arising from the colonial transgression that forced different ethnic groups into one without their consent. This, as the study reveals that right from history, the management of a federal structure whether by nationalism, democracy or ethnically segmented structure has often been with great pain. This is made worse when the people or nations forming the federal structure or union are not in their self determinant of the union, but by external centripetal force as the case with Nigeria.

ii. Politics of selfishness, bitterness and acrimony in Nigeria result to insecurity in the country. Leadership vacuum and neglect by our leaders paved way to such violent vices such as the Niger Delta militants, Boko Harams and armed banditry as a result 
of frustration on the side of the citizens leading to aggression on the government and the ruling elites.

iii. None respect to human dignity and rule of law as a result of class differentials are the major sources of provocation and anger on the side of the citizens.

iv. The Nigerian government is not strong in tackling the issue of insecurity and respect for rule of law. This scenario quite underscores the complicity of the Nigeria's political leadership and the fact that the security agencies are mere shadow-chasing outfits. Government should also make life better for the citizens to avoid further frustration and recourse to violence against the other.

\section{Conclusion}

This study has been able to explain security and rule of law in Nigeria as an issue of national debate. From the revelation of the study, security challenge and neglect to rule of law are matter of leadership vacuum. The study contends that any threat to security and human dignity should receive immediate and adequate attention from the leadership to eschew its attendant devastating consequences.

The major conclusion of this study therefore is that leadership at all levels of the society should take threat to security and non respect to rule of law as a socio-political challenge that must receive immediate positive attention it requires whenever they occur. This if noted would make the Nigerian leadership at all levels to stake all efforts in maintaining both internal and external security of the nation and respect for rule of law and human dignity.

\section{Recommendations}

Arising from the major findings of the study the following nuggets are recommended for policy options:

- The leadership and political class should conduct themselves in line with constitution of this country. By so doing, the principles of rule of law and respect for human dignity would be achieved, hence, the entrenchment of the principles of rule of law in the constitution.

- Leadership in Nigeria should shun politicizing and playing to the galaxy in matters of security threats. Misconception leads to evolving temporary and fragile solution that is not based on reality and the root cause of the matter in question. This creates avenue for possible reoccurrence of the matter within shortest time.

- $\quad$ Nigerians should be made to see the present security challenges as a collective war to fight and win. Therefore, there should be no better strategy for winning this battle than offensive defense through proactive measures of preemptive action by taking the battle to the creeks, villages and terrorist enclaves in the surrounding bushes and uncompleted buildings littering Nigerian States collectively.

- There should be the renewed political impetus for social reorientation of our youths through sincerity of purpose, justice and fairplay as the rightful process of improving their mental, moral and intellectual beings in order to ensure the security of Nigeria and her environment under intelligence communities. 
- Intelligence departments should be established and empowered legally at various local government areas of the country to take up the challenge of ensuring peace and security, hence, virtually all communal clashes have their roots in communities and this can lead to macro security threat.

- There should be regular sensitization of the general public on the need to maintain peace and security in the society. Also, security agents such as the police, the state security services (SSS) should maintain security of information given by any concerned individual on security threat.

- The philosophy of job creation and wealth should go beyond lip service of government to be able to engage our youth meaningfully in economic production to reduce unemployment.

\section{References}

Akpuru-Aja, A. (2007) Basic Concepts, Issues and strategies of peace and Conflict Resolution; Nigeria-Africa Case Studies. Enugu: Keny and Brother Enterprise.

Eke, O. (2010) Achieving Millennium Development Goals in the Health Sector: the Role of labour leadership. African Journal of Social Sciences vol. 3

Eke, O. (2010) Politics, Oil Wealth and Crisis of Development. Abakaliki: Willy Rose and Appleseed.

Etuk, S. (2009) Akpabio and Security Challenges. Uyo: Vanguard, December 6, PP 58.

Nwali, T. B. (2011) Management of Communal Conflicts in Ebonyi State: A Study of Ndufu and Ndiegu Amagu Ikwo Land Dispute. Unpublished M.Sc. Dissertation, Ebonyi State University, Abakaliki.

Nwali, T. B.(2013) Nigerian Government and Administration. Abakaliki: De Oasis Communications \& Publishers.

Okoli, F.C. (2013) Foundations of Government and Politics. Abakaliki: De Communications \& publishers.

Oboke, C., Eje, B. O. and Igwe, L. E. (2012) Nigerian Internal Security as Leadership Challenge. Journal of Arts and Social Science Vol 2 (2) .

Imobighe, T. A. (1980) Analysis of Threats within the African Context. Kuru: National Institute for Policy and Strategic Studies.

Honby, A. S. (2005) Okford Advanced Learner's Dictionary of Contemporary English $7^{\text {th }}$ Edition. 
Rockley, L. E. and Hill, D. A. (1981) Security, Its Management and Control. London: Business Books Ltd.

Jhingan, M. L. (2013) The Economics of Development and Planning. New Dechvrinda Publications.

Nkwede, J. O. (2010) Democracy, Civil Society and Kidnapping in the South- Eastern Nigeria: A Search for Remediation. African Journal of Social Sciences vol. 1 (1) 